Original Research Paper

\title{
Pemberdayaan Masyarakat dengan Pembuatan Ekoenzim Berbasis Rumah Tangga di Desa Lajut
}

\author{
Immy Suci Rohyani ${ }^{1 *}$, Nada Anjani' ${ }^{1}$, Intan Permata Sari ${ }^{2}$, Baiq Dea Nisrina Atika ${ }^{3}$, Nur Yani Wulandari ${ }^{4}$ \\ ${ }^{\text {I}}$ Fakultas Matematika dan Ilmu Pengetahuan Alam, Universitas Mataram, Mataram, Indonesia; \\ ${ }^{2}$ Fakultas Pertanian, Universitas Mataram, Mataram, Indonesia. \\ ${ }^{3}$ Fakultas Ekonomi dan Bisnis, Universitas Mataram, Mataram, Indonesia. \\ ${ }^{4}$ Fakultas Teknologi Pangan, Universitas Mataram, Mataram, Indonesia
}

https://doi.org/10.29303/jpmpi.v3i2.1396

Sitasi: Rohyani, I. S., Anjani, N., Sari, I. P., Atika, B. D. N \& Wulandari, N. Y. (2022). Pemberdayaan Masyarakat dengan Pembuatan Ekoenzim Berbasis Rumah Tangga di Desa Lajut. Jurnal Pengabdian Magister Pendidikan IPA, $5(1)$

\section{Article history}

Received: 11 Januari 2022

Revised: 11 Februari 2022

Accepted: 27 Februari 2022

*Corresponding Author: Immy Suci Rohyani, Fakultas

Matematika dan Ilmu

Pengetahuan Alam, Universitas Mataram, Mataram, Indonesia; Email: immysuci@yahoo.co.id

\begin{abstract}
Sampah merupakan masalah besar yang sering kita jumpai dalam kehidupan sehari-hari, salah satunya di Desa Lajut Kecamatan Praya Tengah Kabupaten Lombok Tengah. Kurangnya kesadaran masyarakat dan tidak tersedianya sarana dan prasarana kebersihan, seperti tidak adanya Tempat Pembuangan Sementara (TPS), tong sampah dan truk pengangkut sampah di Desa Lajut merupakan permasalahan yang cukup signifikan untuk diselesaikan. Dilakukannya kegiatan pemberdayaan masyarakat ini bertujuan untuk meningkatkan pemahaman masyarakat di Desa Lajut khususnya ibu rumah tangga mengenai pemanfaatan sampah buah dan sayur berbasis rumah tangga menjadi ekoenzim. Ekoenzim merupakan hasil pengolahan sampah buah, bunga ataupun sisa sayur yang mengalami proses fermentasi dengan bantuan gula (molase). Sosialisasi dilakukan dengan metode penyuluhan dan pendampingan langsung terhadap masyarakat partisipan. Program pemberdayaan masyarakat dengan pembuatan ekoenzim berbasis rumah tangga ini dinyatakan tepat sasaran karena peran dan respon aktif dari masyarakat dalam proses pembuatan ekoenzim. Dengan demikian kedepannya diharapkan sampah di Desa Lajut dapat dikurangi dengan mengolah sampah yang diproduksi oleh masyarakat menjadi sesuatu yang bermanfaat, salah satunya ekoenzim.
\end{abstract}

Keywords: Ekoenzim; Pemberdayaan masyarakat; Sampah rumah tangga.

sarana kebersihan, yaitu tidak adanya Tempat Pembuangan Sementara (TPS), tidak ada tong sampah, gerobak sampah, truk pengangkut sampah dan tidak ada tempat pengelolaan sampah. Hal tersebut menjadi kendala terkait oprasional sampah di Desa ini. Program kerja mahasiswa KKN Tematik UNRAM di Desa Lajut menggagas gerakan "Pengelolaan dan Penerapan Budaya mengurangi Sampah berbasis Rumah Tangga di Desa Lajut Kecamatan Praya Tengah, Kabupaten Lombok Tengah" dengan mendorong gerakan zero waste dimana salah satu programnya adalah pengolahan sampah organik buah dan sayur menjadi ekoenzim. 
Ekoenzim merupakan hasil pengolahan sampah organik seperti buah, bunga ataupun sisa sayur yang mengalami proses fermentasi. Proses fermentasi ini dibantu oleh adanya gula (molase). Ekoenzim dapat menjadi cairan multiguna dan aplikasinya untuk kebutuhan rumah tangga meliputi campuran deterjen, pembersih lantai, dan pembersih kerak. Pada dasarnya ekoenzim mempercepat reaksi bio-kimia di alam untuk menghasilkan enzim yang berguna dengan menggunakan sampah buah atau sayuran. Enzim dari "sampah" ini adalah salah satu cara manajemen sampah dengan memanfaatkan sisa buah dan sayur di Desa Lajut untuk dijadikan cairan pembersih untuk rumah tangga maupun sebagai pupuk alami dan pestisidia yang efektif. Pengolahan sampah menjadi ekoenzim belum banyak diketahui oleh masyarakat di Desa Lajut. Oleh karena itu, KKN tematik Universitas Mataram melakukan pemberdayaan masyarakat untuk memanfaatkan sampah buah dan sayur menjadi ekoenzim. Tujuan program ini secara spesifik adalah meningkatkan pemahaman masyarakat Desa Lajut khususnya ibu rumah tangga mengenai pemanfaatan sampah buah dan sayur berbasis rumah tangga menjadi ekoenzim. Selain itu, pemanfaatan sampah rumah tangga ini juga termasuk salah satu bentuk konservasi lingkungan.

\section{Metode}

Kegiatan pemberdayaan masyarakat dengan pembuatan ekoenzim berbasis rumah tangga di Desa Lajut ini dilaksanakan pada tanggal tanggal 26 Januari 2022 dengan fokus partisipan ibu rumah tangga di dusun Ledang, Desa Lajut, kecamatan Praya Tengah. kegiatan dilakukan dengan metode penyuluhan dan pendampingan langsung terhadap masyarakat partisipan. Penyuluhan dimulai dengan memberikan pemahaman mengenai apa itu ekoenzim dan kegunaannya. Selanjutnya dilakukan pendampingan dalam pembuatan ekoenzim hingga masa simpan. Proses pembuatan ekoenzim ini dilakukan dalam 3 tahap yaitu persiapan, tahap pembuatan hingga masa penyimpanan. Pembuatan ekoenzim ini dimulai dengan menyiapkan alat dan bahan yang dibutuhkan, yakni berupa gula pasir, kulit jeruk dan buni yang yang diperoleh dari sampah masyarakat partisipan, dan air dengan perbandingan 1:3:10 (Ramadani dkk., 2019). Sedangkan alat yang digunakan hanyalah botol plastik ukuran 2L. Wadah yang digunakan hendaknya terbuat dari plastik dan menghindari wadah berbahan kaca, karena dapat menyebabkan wadah pecah akibat tekanan gas yang dihasilkan oleh mikroba fermentasi (Rambe, 2021). Selanjutnya semua bahan dimasukkan kedalam botol plastik dengan tutup dengan urutan air terlebih dahulu, gula kemudian kulit buah yang telah dipotong dengan ukuran kecil untuk mempercepat proses pembusukan oleh mikroba, kemudian disimpan dalam suhu ruang selama 3 bulan (Chandra, dkk., 2020) pada 2 minggu pertam tutup ekoenzim hendaknya dibuka secara rutin untuk mengeluarkan gas yang diihasilkan dari proses fermentasi yang terjadi. Namun pada minggu ketiga dan setrusnya produksi gas akan mulai berkurang (Awalina, 2021).

\section{Hasil dan Pembahasan}

Kegiatan sosialisasi ini dilakukan dengan jumlah peserta sebanyak 6 orang, dengan sasaran penyuluhan yaitu ibu-ibu rumah tangga yang ada di Dusun Ledang, Desa Lajut, Kecamatan Praya Tengah, Kabupaten Lombok Tengah. Kegiatan ini dilakukan melalui pendekatan konsultatif dan pendampingan secara langsung kepada masyarakat peserta. Kegiatan sosialisasi ini akan meemberikan gambaran kepada masyarakat berupa edukasi pemilahan sampah, pengetahuan tentang pemanfaatan sampah organik menjadi bahan pembersih rumah tangga berkonsep ekoenzim, dan pembuatan ekoenzim melalui pendampingan.

Kegiatan pemberdayaan masyarakat dengan pembuatan ekoenzim di Desa Lajut ini dimulai dari tahap persiapan, dimana dilakukan kooradinasi lokasi dan waktu pelaksanaan sosialisasi oleh kelompok KKN bersama kelompok ibu rumah tangga yang ada di Dusun Ledang, Desa Lajut. Lokasi kegiatan bertempat di Posko KKN Desa Lajut yang dilaksanakan pada tanggal 26 Januari 2022 pukul 16.30-17.30 Selanjutnya dilakukan persiapan alat dan bahan yang dibutuhakan untuk pembuatan ekoenzim.

Tabel 1. Alat Pembuatan Ekoenzim

Alat Pembuatan Ekoenzim
Botol Plastik
Gunting
Pisau 
Tabel 2. Bahan Pembuatan Ekoenzim

\begin{tabular}{c}
\hline Bahan Pembuatan Ekoenzim \\
\hline Air \\
Bunei \\
Gula \\
Kulit Jeruk \\
Kulit Rambutan \\
Mangga \\
\hline
\end{tabular}

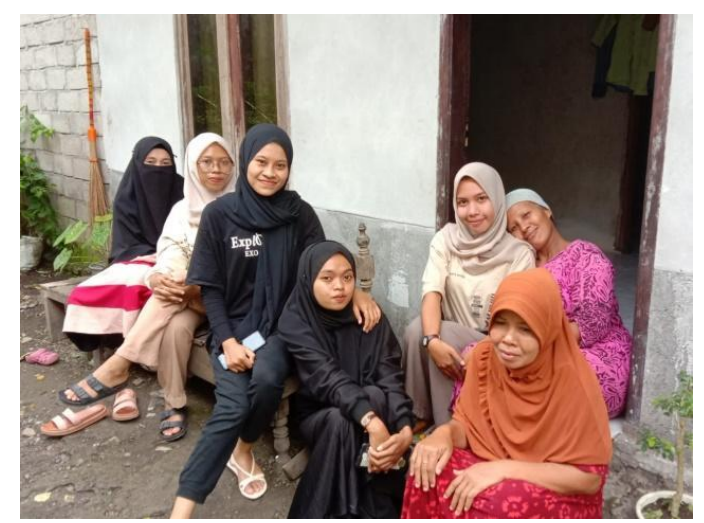

Gambar 1. Koordinasi lokasi dan dan waktu kegiatan
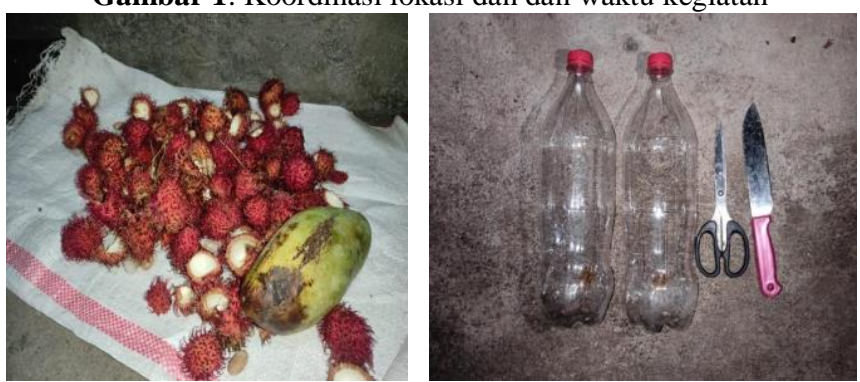

Gambar 2. Persiapan alat dan bahan

Tahap selanjutnya adalah tahap pelaksanaan, pada tahap pelaksanaan ini, masyarakat partisipan, yakni ibu rumah tangga diperkenalakan dengan ekoenzim dan fungsinya sebagai cairan pembersih rumah tangga, seperti pembersih lantai, pembersih kaca dan lain sebagainya. Penyuluhan ini dilakukan dengan pemaparan teori mengenai ekoenzim secara langsung (Chandra, dkk., 2020). Teori yang disampaikan pada tahap penyuluhan ini yaitu, pengertian ekoenzim, manfaat ekoenzim, pentingnya membuat ekoenzim, bahan yang digunakan dan bagaimana cara membuatnya (Mardiani, dkk., 2021) Diketahui bahwa pengetahuan masyarakat Desa Lajut tentang pengelolaan sampah buah bunga dan sayur sangat minim. Oleh karena itu, pembuatan ekoenzim yang mudah dan sedernaha dapat menarik perhatian dan antusiasme masyarakat, terutama ibu-ibu untuk mengolah sampah buah dan sayur hasil rumah tangga mereka. Hal ini ditunjukkan dengan partisipasi ibu rumah tangga yang terlibat secara aktif dalam demonstrasi pembuatan ekoenzim (gambar 1). Pemberdayaan ini dihapkan dapat meningkatkan pengetahuan dan kesadaran masyarakat, terutama ibu rumah tangga tentang pemanfaatan sampah buah dan sayur rumah tangga yang diproduksi setiap harinya.

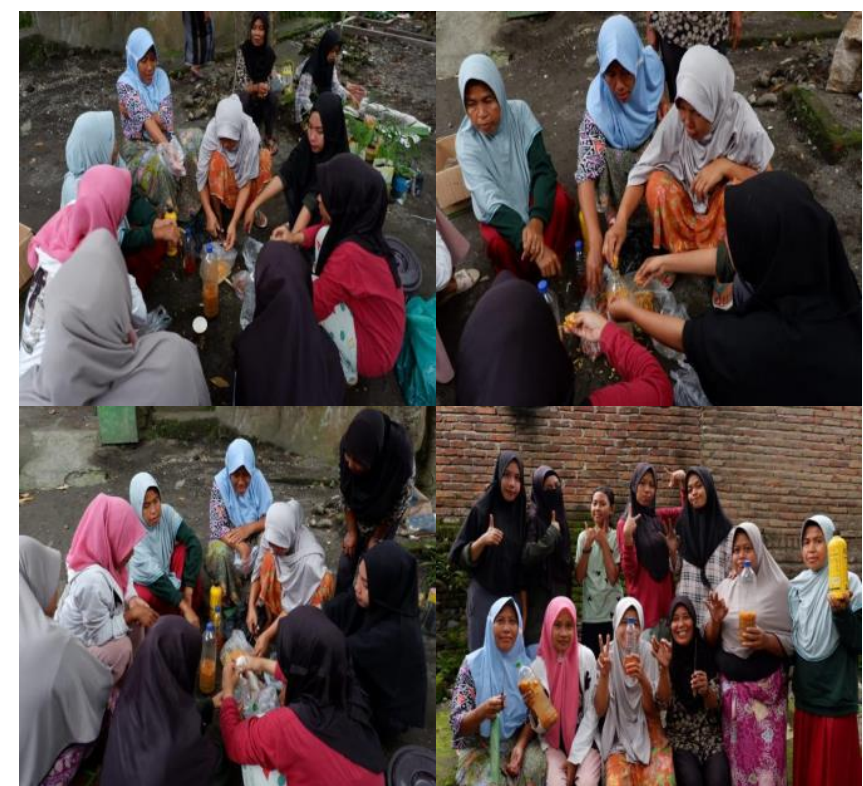

Gambar 3. Partisipasi masyarakat dalam pembuatan ekoenzim

\section{Kesimpulan}

Telah dilaksanakan program kerja KKN tematik Universita Mataram di Desa Lajut Kecamatan Praya Tengah, Kabupaten Lombok Tenga. Berdasarkan diskusi yang dilakukan bersama peserta sosialisasi diketahui bahwa masyarakat kurang memahami cara pengolahan sampah organik khususnya berbasis rumah tangga, sehingga dengan adanya pemberdayaan masyarakat mengenai sampah dengan pembuatan ekoenzim khususnya kalangan ibu-ibu di harapkan dapat mengurangi sampah yang diproduksi dengan memilah dan mengolahnya menjadi sesuatu yang bermanfaat.Kegiatan ini perlu dilanjutkan berupa mentoring kepada seluruh warga di Desa Lajut melalui kerjasama antara pemerintah Desa dan ketua RT. 


\section{Ucapan Terima Kasih}

Kepada kepala desa dan seluruh jajaran perangkat desa yang telah mendukung kegiatan pemberdayaan masyarakat dengan pembuatan ekoenzim berbasis rumah tangga di desa Lajut yang termasuk ke dalam program kerja kuliah kerja nyata ini dengan mengizinkan masyarakat untuk hadir dalam kegiatan tersebut. Kepada ibu-ibu RT 02 Dusun Ledang yang telah meluangkan waktu dan tenaga dalam kegiatan ini.

\section{Daftar Pustaka}

Chandra, Y. N., Hartati, C. D., Wijayanti, G., \& Gunawan, H. G. 2020. Sosialisasi Pemanfaatan Limbah Organik Menjadi Bahan Pembersih Rumah Tangga. Prosiding Seminar Nasional Pengabdian Kepada Masyarakat. Jakarta. 20 Desember.

Mardiani, I. N., Nurhidayanti, N., \& Huda, M. 2021 Sosialisasi Pemanfaatan Limbah Organik Sebagai Bahan Baku Pembuatan Eco Enzim Bagi Warga Desa Jatireja Kecamatan Cikarang Timur Kabupaten Bekasi. Jurnal Abdimas Pelita Bangsa, vol 2, hal 42-47.

Ramadani, A. H., Rosalina, R., \& Ningrum, R. S. 2019. Pemberdayaan Kelompok Tani Dusun Puhrejo dalam Pengolahan Limbah Organik Kulit Nanas sebagai Pupuk Cair Eco-enzim. Prosiding Seminar Nasional Hayati. Kediri. 5 Oktober.

Rambe, T. R. 2021. Sosialisasi dan Aktualisasi EcoEnzyme sebagai Alternatif Pengolahan Sampah Organik Berbasis Masyarakat di Lingkungan Perumahan Cluster Pondok II. Jurnal Pengabdian kepada Masyarakat, vol 2, hal 3640.

Yanti, D., \& Awalina, R. 2021. Sosialisasi dan Pelatihan Pengolahan Sampah Organik Menjadi EcoEnzyme. Jurnal Warta Pengabdian Andalas, vol 28, hal 84-90. 